\title{
OPTIMASI FORMULA MATRIKS KITOSAN DENGAN METILSELULOSA PADA PELEPASAN TERKENDALI SEDIAAN GRANUL TEOFILIN
}

\author{
Submitted : 13 Nov 2015 \\ Edited : 15 Des 2015 \\ Accepted : 21 Des 2015
}

\author{
Suprianto, S.Si., M.SI., Apt. \\ Dosen Kopertis Wilayah I dpk Stikes Helvetia Medan \\ Email : ekahasbi@gmail.com
}

\begin{abstract}
The in vitro study was carried out on the release of active ingradient theophylline from granules prepared by moist granulation method. The granule matrix was prepared from the mixture of chitosan isolated from SwaIIo shrimp (Metapenaeus monoceros) (in accordance with the Protan Laboratories, Inc standard requirement) and methylceliuiose $1500 \mathrm{cps}$. The granules were filled into $850 \mathrm{mg}$ capsules containing $200 \mathrm{mg}$ theophylline. The maximum weight of chitosan and methylcellulose for each capsule was determined by factorial design $2^{2}$.The result showed that, when the amount of chitosan was kept constant, an increase in the amount of methylcellulose will increase the release rate of theophylline from granules. The optimum weight of chitosan and methyIcelIuIose are $609.24 \mathrm{mg}$ and $20.00 \mathrm{mg}$, respectively for one capsule.
\end{abstract}

Keywords : theophylline, chitosan and methylcellulose

\section{PENDAHULUAN}

Pemberian obat secara berulang sering menyebabkan pola pelepasan obat tidak terkontrol sehingga kurva konsentrasi obat dalam plasma berfluktuasi. Produk pelepasan terkendali menawarkan beberapa keuntungan, antara lain: kadar obat dalam plasma relative konstan, memperkecil toksisitas, menurunkan efek samping akibat fluktuasi kadar obat, frekuensi pemberian obat sekali sehari dan menjamin terapi optimum ${ }^{(1)}$. Obat dalam bentuk produk tersebut harus mempunyai waktu paruh lebih kecil dari 8 jam dan tidak kurang dari satu jam, diabsorbsi efektif di ujung usus halus dan dosis tidak lebih dari satu gram serta indeks terapi sempit ${ }^{(2,3)}$.

Teofilin adalah salah satu bronkodilator dengan indeks terapi sempit, yaitu berkisar antara $10-20 \mathrm{mcg} / \mathrm{ml}$ darah, dapat diberikan pada penderita asma kronis, dosis lazim $200 \mathrm{mg}$ sekali pemakaian dan waktu paruh 3-7 jam serta mempunyai harga pKa sebesar $8,6^{(4)}$.

Bahan tambahan yang digunakan sebagai pengikat harus inert, tidak toksik dan mampu melepaskan bahan obat relatif konstan dalam jangka waktu tertentu ${ }^{(3)}$. Metilselulosa merupakan polimer yang larut larut dalam air sedangkan kitosan suatu polimer yang tidak larut dalam air berfungsi sebagai pengikat yang inert dan tidak toksik ${ }^{(5)}$.

Kitosan telah dimanfaatkan untuk membuat granul dengan bahan aktif indometasin dan dilaporkan bahwa granul kitosan mempunyai potensi sebagai sediaan oral pelepasan terkendali ${ }^{(6)}$.

Kitosan merupakan senyawa yang tidak larut dalam air, larutan basa kuat, H2S04 dan beberapa pelarut organik, seperti: alkohol, aseton, dimetilformamida dan dimetilsulfoksida, sedikit larut dalam $\mathrm{HCl}, \mathrm{HN} 03$ dan $\mathrm{H} 3 \mathrm{P} 04$ 0,5\% dan larut baik dalam asam asetat ${ }^{(7)}$.

Kitosan mempunyai gugus amino sehingga kitosan mempunyai reaktifitas kimia yang tinggi dan menyumbangkan sifat elektrolit polikation ${ }^{(8,9)}$. Metilselulosa telah digunakan untuk membuat matriks yang dapat mengontrol pelepasan obat dari sediaan lepas lambat ${ }^{(10)}$. Metilselulosa dinyatakan menghasilkan pelepasan obat mendekati orde nol dari matriks yang tidak larut dalam air, misalnya: gliseril stearat, alkohol berlemak, lilin dan etilselulosa ${ }^{(3)}$.

Penelitian optimasi formula matriks kitosan dengan metilselulosa pada pelepasan terkendali 
sediaan granul teofilin dilakukan dengan menggunakan rancangan faktorial.

\section{BAHAN DAN ALAT}

Bahan yang digunakan dalam penelitian ini antara lain teofilin p.a (Metcorp, Ltd), asam klorida p.a (E.Merck), natrium hidroksida p.a (E.Merck), kalium dihidrogen fosfat p.a (E.Merck), kalium klorida p.a (E.Merck), asam asetat glasial p.a (E.Merck), metilselulosa 1500 cps (Wako Pure Industries, LTD) dan kitosan hasil isolasi limbah padat udang Swallo Tambak Sari Mabar (Standar Protan Laboratories, Inc), natrium hipoklorit p.a (E.Merck).

Alat yang digunakan diantaranya Spektrofotometer ultra violet (Milton Roy 21D), alat disolusi (Erweka), pengaduk magnetik (Ikamag), timbangan listrik (Sartorius), pH-meter stick (HBI), alat-alat gelas dan lain-lain.

\section{METODE}

Metode penelitian pelepasan terkendali teofilin sediaan granul campuran metilselulosa dengan kitosan meliputi:

\section{Pembuatan Granul Teofilin}

Formula $\mathrm{F}_{1}$ sampai $\mathrm{F}_{4}$ dibuat dengan melarutkan teofilin dalam larutan natrium hidroksida $0,1 \mathrm{~N}$ sebanyak $5 \mathrm{ml}$ di tambah gel kitosan-metilselulosa. Gel dibuat dengan menambahkan $10 \mathrm{ml}$ asam asetat $10 \%$ setiap 400 mg kitosan. Kemudian pelarut diuapkan pada suhu $60^{\circ} \mathrm{C}$ hingga massa dapat digranulasi dengan mesh 12. Kemudian didiamkan pada suhu kamar selama 6 jam dan dikeringkan pada suhu $60^{\circ} \mathrm{C}$ selama 8 jam. Sediaan dibuat dengan berbagai formula seperti terlihat pada Tabel 1 .

Tabel 1. Formula Matriks Sediaan Granul Teofilin

\begin{tabular}{|c|c|c|c|c|}
\hline No & Formula & $\begin{array}{c}\text { Teofilin } \\
(\mathrm{mg})\end{array}$ & $\begin{array}{c}\text { Kitosan } \\
(\mathrm{mg})\end{array}$ & $\begin{array}{c}\text { Metilselulo } \\
\text { sa }(\mathrm{mg})\end{array}$ \\
\hline 1 & $\mathrm{~F}_{1}$ & 200 & 600 & 20 \\
\hline 2 & $\mathrm{~F}_{2}$ & 200 & 600 & 400 \\
\hline 3 & $\mathrm{~F}_{3}$ & 200 & 800 & 20 \\
\hline 4 & $\mathrm{~F}_{4}$ & 200 & 800 & 400 \\
\hline 5 & $\mathrm{~F}_{5}$ & 200 & $\mathrm{X}_{1}$ & $\mathrm{X}_{2}$ \\
\hline
\end{tabular}

Keterangan:

$\mathrm{X}_{1}=$ Massa Kitosan Optimum

$\mathrm{X}_{2}=$ Massa Metilselulosa Optimum

\section{Penetapan Konsentrasi Teofilin dalam Granul}

Seratus miligram granul dimasukkan ke dalam beaker glass dan ditambah $100 \mathrm{ml}$ medium pH 6,8 dan diaduk selama 8 jam dengan pengaduk magnetik. Alikuot diambil dan ditentukan serapan pada panjang gelombang maksimum dengan spektrofotometer ${ }^{(11)}$.

\section{Uji Disolusi}

Pelepasan obat secara in vitro ditentukan dengan memodifikasi metode uji disolusi USP XXII dengan menggunakan keranjang berputar. Granul yang mengandung kira-kira $200 \mathrm{mg}$ teofilin dimasukkan ke dalam keranjang dan di putar dengan kecepatan 100 rpm pada ketinggian kirakira $2 \mathrm{~cm}$ dari dasar labu yang berisi $1000 \mathrm{ml}$ medium II ( $\mathrm{pH} 6,8)$ pada suhu $37 \pm 0,5^{0} \mathrm{C}^{(6,12)}$. Alikuot dipipet dengan volume, selang dan lama waktu tertentu dan diukur serapan pada panjang gelombang $270 \mathrm{~nm}$ dengan spektrofotometer ultra violet. Jumlah teofilin yang dilepaskan ditentukan dengan menggunakan kurva kalibrasi teofilin. Volume cairan dalam labu tetap dijaga $1000 \mathrm{ml}$ dengan menambahkan medium yang sama dan setiap formula diuji 6 kali. Uji disolusi juga dilakukan dengan menggunakan medium I dan serapan diukur pada panjang gelombang $272 \mathrm{~nm}^{(11)}$. Jumlah teofilin yang terlepas ditentukan dengan kurva kalibrasi teofilin.

\section{Penetapan Massa Optimum Kitosan dan Metilselulosa}

Massa optimum kitosan dan metilselulosa sebagai pengikat teofilin dengan massa maksimum kapsul 1 gram dan dosis muat $150 \mathrm{mg}$ ditentukan dengan rancangan faktorial 22 melalui studi kombinasi kitosan dengan metilselulosa seperti Tabel $2^{(13)}$.

Massa rata-rata granul yang didisolusi dari Tabel 2, diamati untuk menentukan koefisien persamaan 1. Demikian juga respon terhadap persen kumulatif teofilin terlarut sampai waktu tertentu sehingga diperoleh koefisien persamaan $2^{(13)}$. 
Tabel 2. Rancangan Faktorial Kombinasi Kitosan-Metilselulosa

\begin{tabular}{|c|c|c|c|c|c|c|}
\hline \multirow{2}{*}{ No } & \multirow{2}{*}{ Formula } & \multicolumn{2}{|c|}{ Transpormasi Potensi } & \multicolumn{2}{c|}{ Respon } \\
\cline { 3 - 7 } & & $\mathrm{AX}_{1}$ & $\mathrm{BX}_{2}$ & $\mathrm{CX}_{1} \mathrm{X}_{2}$ & $\mathrm{Y}_{1}$ & $\mathrm{Y}_{2}$ \\
\hline 1 & $\mathrm{~F}_{1}$ & -1 & -1 & +1 & $\mathrm{Y}_{11}$ & $\mathrm{Y}_{21}$ \\
\hline 2 & $\mathrm{~F}_{2}$ & -1 & +1 & -1 & $\mathrm{Y}_{12}$ & $\mathrm{Y}_{22}$ \\
\hline 3 & $\mathrm{~F}_{3}$ & +1 & -1 & -1 & $\mathrm{Y}_{13}$ & $\mathrm{Y}_{23}$ \\
\hline 4 & $\mathrm{~F}_{4}$ & +1 & +1 & +1 & $\mathrm{Y}_{14}$ & $\mathrm{Y}_{24}$ \\
\hline
\end{tabular}

Keterangan :

$\mathrm{AX}_{1}=$ transformasi potensi kitosan.

$\mathrm{BX}_{2}=$ transformasi potensi metilselulosa.

$\mathrm{CX}_{1} \mathrm{X}_{2}=$ transformasi potensi interaksi.

$\mathrm{Y}_{1}=$ respon massa rata-rata granul terdisolusi.

$\mathrm{Y}_{2}=$ respon persen kumulatif teofilin terlarut.

$Y_{1}=\beta 0+\beta_{1} X_{1}+\beta_{2} X_{2}+\beta_{12} X_{1} X_{2} \ldots \ldots \ldots \ldots 1$

$Y_{2}=\beta o+\beta_{2} X_{2}+\beta_{2} X_{2}+\beta_{12} X_{1} X_{2} \ldots \ldots \ldots \ldots .2$

Massa kitosan maupun metilselulosa terendah dan tertinggi yang direncanakan pada Tabel 2, disubstitusikan pada persamaan 3 dan $4 .^{(3)}$

$A X_{1}=\frac{A-\left(X_{13}+X_{22}\right) / 2}{\left(X_{13}-X_{11}\right) / 2} \ldots \ldots \ldots \ldots \ldots \ldots \ldots . . \ldots \ldots \ldots \ldots \ldots \ldots \ldots$
$B X_{2}=\frac{B-\left(X_{22}+X_{21}\right) / 2}{\left(X_{22}-X_{21}\right) / 2} \ldots \ldots \ldots \ldots \ldots \ldots \ldots \ldots \ldots$

Keterangan :A = Massa Kitosan Optimum

B = Massa Metilselulosa Optimum

Persamaan 1 dan 2 untuk memprediksi massa maksimum satu kapsul granul teofilin dan persen kumulatif teofilin yang terlarut pada waktu tertentu. Sedangkan persamaan 3 dan 4 untuk menentukan massa kitosan dan metilselulosa optimum berdasarkan transformasi potensi kitosan dan metilselulosa dari prediksi massa maksimum satu kapsul granuI teofilin melalui parsamaan 1.

\section{HASIL DAN PEMBAHASAN}

\section{Penentuan Konsentrasi Teofilin dalam Granul}

Tabel 3 menunjukkan jumlah obat yang terperangkap di dalam granul makin kecil dengan bertambah konsentrasi kitosan atau campuran kitosan dengan metilselulosa. Hal ini diakibatkan jumlah obat yang terperangkap di dalam granul merupakan perbandingan antara bahan obat dengan pengikat.
Tabel 3. Konsentrasi Teofilin dalam Granul

\begin{tabular}{|c|c|c|}
\hline N0. & Formula & Teofilin (\%) \\
\hline 1 & $F_{1}$ & $16,3194 \pm 0,5373$ \\
\hline 2 & $F_{2}$ & $19,1147 \pm 0,8360$ \\
\hline 3 & $F_{3}$ & $13,9460 \pm 0,5466$ \\
\hline 4 & $F_{4}$ & $23,2916 \pm 0,8326$ \\
\hline
\end{tabular}

Keterangan: $*=$ Standar deviasi $(\mathrm{n}=3)$.

\section{Pemeriksaan Uji Disolusi}

Interpretasi data disolusi (Tabel 4) dilakukan dengan mengamati profil pelepasan teofilin masingmasing formula. Profil pelepasan dibuat dengan memplotkan persen teofilin yang terlepas versus waktu dalam menit (Gambar 1). Proses pelepasan obat yang paling lambat adalah formula $\mathrm{F}_{3}$, dengan komposisi kitosan-metilselulosa 40 : 1 (b/b). Hal ini menunjukkan bahwa kitosan bersifat kationik akan lebih memperlambat, hal ini disebabkan kitosan berikatan ionic dengan teofilin sedangkan dengan metilselulosa hanya terdispesi.

Pelepasan teofilin melalui sistem tekanan osmosa, difusi dan erosi serta pengontrolan reaksi kimia (chemically controlled system). Hal ini disebabkan pengembangan granul matriks kitosan sampai $3 / 2$ kali volume awal, perpindahan zat terlarut dari konsentrasi tinggi ke konsentrasi rendah dan pelarutan matriks metilselulosa yang mengandung teofilin serta pemutusan ikatan ion teofilin dengan kitosan.

Penentuan laju pelepasan teofilin granul dilakukan dengan membuat persamaan regresi masing-masing sistem pelepasan obat dari sediaan. Laju orde nol diperoleh dengan plot antara konsentrasi kumulatif teofilin terlarut dengan waktu dan harus diperoleh garis lurus dengan koefisien determinasi tertinggi. Laju orde satu dilakukan dengan plot antara logaritma pengurangan konsentrasi zat aktif dengan waktu, juga dan harus diperoleh garis lurus dengan koefisien determinasi tertinggi ${ }^{(2,14)}$. Sedangkan laju orde Higuchi dilakukan dengan plot antara konsentrasi kumulatif teofilin terlarut dengan akar waktu dan dan harus diperoleh garis lurus dengan koefisien determinasi tertinggi ${ }^{(3,5,14)}$.

Model laju pelepasan obat ditentukan oleh harga koefisien determinasi terbesar dari ketiga analisis regresi model laju pelepasan obat. Hasil analisis laju pelepasan obat untuk orde nol, orde satu dan orde Higuchi ditampilkan pada Tabel 5. 
Tabel 4. Data Disolusi Granul Formula $F_{1}$ sampai $F_{4}$ dalam Medium $\mathrm{pH}=6,8$

\begin{tabular}{|c|c|c|c|c|c|}
\hline \multirow{2}{*}{ No } & \multirow{3}{*}{ Waktu (Menit) } & \multicolumn{4}{|c|}{ Persen Kumulatif Teofilin Terlarut* } \\
\cline { 3 - 6 } & & $\mathrm{F}_{1}$ & $\mathrm{~F}_{2}$ & $\mathrm{~F}_{3}$ & $\mathrm{~F}_{4}$ \\
\hline 1 & 30 & $25,1686 \pm 0,4849$ & $46,8708 \pm 0,6365$ & $16,4703 \pm 0,4396$ & $34,2891 \pm$ \\
\hline 2 & 60 & $41,9574 \pm 0,3153$ & $70,0356 \pm 0,5974$ & $31,7956 \pm$ & $52,6390 \pm 0,7150$ \\
\hline 3 & 90 & $56,6832 \pm 1,0463$ & $83,1038 \pm 1,0953$ & $44,9390 \pm 0,6910$ & $73,8012 \pm 0,6376$ \\
\hline 4 & 120 & $68,6977 \pm 1,0747$ & $92,7326 \pm 1,7290$ & $55,6924 \pm 0,6003$ & $82,1449 \pm 0,9766$ \\
\hline 5 & 150 & $83,4324 \pm 1,8691$ & $96,5443 \pm 0,4089$ & $65,8596 \pm 0,9074$ & $86,3088 \pm 1,0156$ \\
\hline 6 & 180 & $89,0680 \pm 0,4415$ & $98,2740 \pm 0,2951$ & $74,5341 \pm 0,6962$ & $92,8563 \pm 0,9362$ \\
\hline 7 & 210 & $94,1762 \pm 0,6650$ & & $82,9575 \pm 1,3667$ & $93,9706 \pm 1,4758$ \\
\hline 8 & 240 & $96,5699 \pm 0,4457$ & & $90,8485 \pm 0,3905$ & $95,9919 \pm 1,0636$ \\
\hline 9 & 270 & $97,7062 \pm 0,3271$ & & $94,1778 \pm 0,9433$ & $96,8604 \pm 1,3182$ \\
\hline 10 & 300 & & & $96,7803 \pm 1,1948$ & \\
\hline 11 & 330 & & & $97,4002 \pm 1,0919$ & \\
\hline
\end{tabular}

Keterangan : $*$ Standar deviasi $(\mathrm{n}=6)$

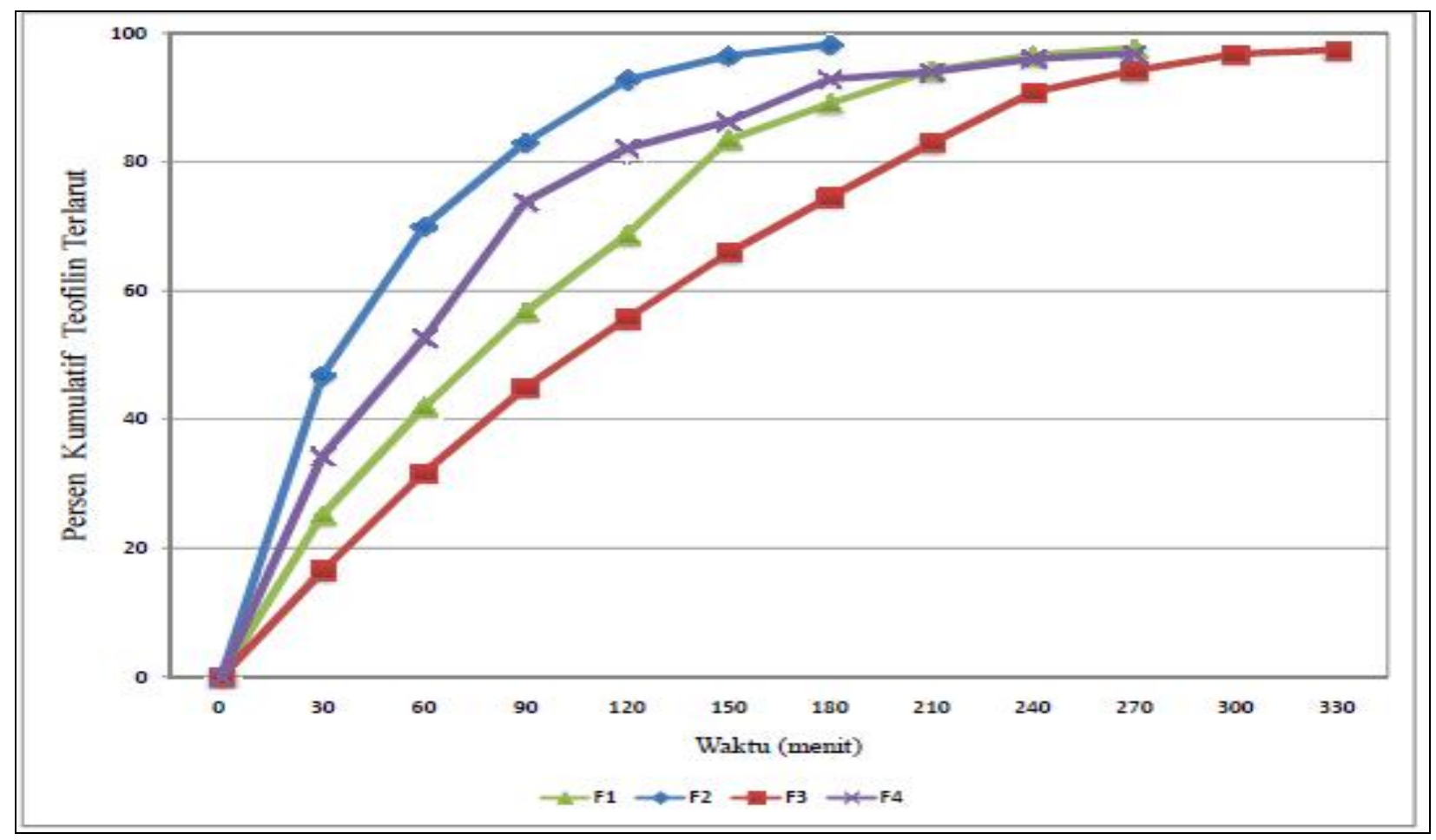

Gambar 1. Profil Pelepasan Teofilin dari Masing-Masing Formula

Tabel 5. Hasil Analisis Kinetika Pelepasan Teofilin dari Matriks Formula Optimasi

\begin{tabular}{|c|c|c|c|c|c|c|}
\hline \multirow{2}{*}{ No. } & \multirow{2}{*}{ Formula } & \multicolumn{2}{|c|}{ Komposisi Matriks } & \multicolumn{3}{c|}{ Nilai Koefisien Determinasi } \\
\cline { 3 - 7 } & & Kitosan(mg) & Metilselulosa $(\mathrm{mg})$ & Orde Nol & Orde Satu & Orde Higuchi \\
\hline 1 & $\mathrm{~F}_{1}$ & 600 & 20 & 0,8332 & 0,8662 & $\mathbf{0 , 9 6 2 2}$ \\
\hline 2 & $\mathrm{~F}_{2}$ & 600 & 400 & 0,6810 & $\mathbf{0 , 9 8 9 6}$ & 0,9431 \\
\hline 3 & $\mathrm{~F}_{3}$ & 800 & 20 & 0,8844 & 0,9251 & $\mathbf{0 , 9 5 4 5}$ \\
\hline 4 & $\mathrm{~F}_{4}$ & 800 & 400 & 0,6354 & $\mathbf{0 , 9 8 4 5}$ & 0,9151 \\
\hline
\end{tabular}


Koefisien detenminasi tertinggi formula F1, konsentrasi kitosan terendah $(600 \mathrm{mg})$ dan metilselulosa terendah $(20 \mathrm{mg})$ sebesar 0,9622 (Tabel 5) menerangkan bahwa sistem pelepasan obat mengikuti orde Higuchi. Sementara, formula F2, konsentrasi kitosan terendah $(600 \mathrm{mg})$ dan metilselulosa tertinggi (400 $\mathrm{mg})$ mempunyai koefisien determinasi tertinggi 0,9896 (Tabel 5) menerangkan bahwa pelepasan teofilin dari formula F2 mengikuti orde satu. Hal ini menunjukkan bahwa ada batas konsentrasi kitosan yang dapat memberikan kinetika pelepasan teofilin dengan orde tertentu.

Sedangkan koefisien determinasi tertinggi dari formula F3, konsentrasi kitosan tertinggi (800 $\mathrm{mg}$ ) dan metilselulosa terendah $(20 \mathrm{mg})$ sebesar 0,9545 (Tabel 5) menerangkan bahwa pelepasan obat dari formula $\mathrm{F}_{3}$ mengikuti orde Higuchi. Dan koefisien determinasi terbesar formula $F_{4}$, konsentrasi kitosan tertinggi (800 $\mathrm{mg}$ ) dan metilselulosa tertinggi $(400 \mathrm{mg}$ ) sebesar 0,9845 (Tabel 5) menerangkan bahwa pelepasan obat dari formula $\mathrm{F}_{4}$ mengikuti orde satu.

Semakin tinggi konsentrasi kitosan maka pelepasan teofilin cenderung mengikuti laju pelepasan orde Higuchi. Matriks kitosan memberikan pelepasan bahan obat mengikuti orde Higuchi $^{(5,15)}$. Ini menunjukkan bahwa model pelepasan teofilin dari granul kitosan cenderung mengikuti orde Higuchi. Metilselulosa dinyatakan menghasilkan pelepasan obat mendekati orde nol dari matriks yang tidak larut dalam air, misalnya: gliseril stearat, alkohol berlemak, lilin dan etilselulosa ${ }^{(3)}$.

\section{Optimasi Formula Campuran Kitosan dan Metilselulosa}

Tabel 6 menunjukkan massa rata-rata granul teofilin yang mengandung pengikat kombinasi, kitosan dengan metilselulosa yang diamati pada studi kombinasi kitosanmetilselulosa tanpa dosis muatan (Tabel 2).

Berdasarkan massa rata-rata satu kapsul granul teofilin dari Tabel 6 diperoleh koefisien persamaan 1 dan 2, yaitu:

$$
\begin{aligned}
\mathrm{Y}_{1}= & 113,0575+10,3375 \mathrm{X}_{1}+18,8175 \mathrm{X}_{2}+ \\
& 0,1575 \mathrm{X}_{1} \mathrm{X}_{2} \\
\mathrm{Y}_{2}= & 88,6830-4,9879 \mathrm{X}_{1}+6,8821 \mathrm{X}_{2}+ \\
& 2,2791 \mathrm{X}_{1} \mathrm{X}_{2}
\end{aligned}
$$

Tabel 6. Berat Granul Kitosan-Metilselulosa

\begin{tabular}{|c|c|c|}
\hline No. & Formula & Granul (mg) \\
\hline 1 & $\mathrm{~F}_{4}$ & $840,7000 \pm 1,0677^{*}$ \\
\hline 2 & $\mathrm{~F}_{5}$ & $1213,9000 \pm 0,6976$ \\
\hline 3 & $\mathrm{~F}_{6}$ & $1044,2000 \pm 0,8602$ \\
\hline 4 & $\mathrm{~F}_{7}$ & $1432,7000 \pm 1,0033$ \\
\hline
\end{tabular}

Keterangan: * standar deviasi $(\mathrm{n}=6)$

Berat kitosan maupun metilselulosa dari Tabel 1 setelah disubstitusikan pada pesamaan 3 dan 4 diperoleh persamaan 5 dan 6 .

Massa optimum kitosan

$=\{($ Potensi $\mathrm{x} \mathrm{100)}+(700)\} \mathrm{mg}$ 5

Massa optimum metilselulosa

$=\{($ Potensi x 190) $+(210)\} \mathrm{mg}$ 6

Berat maksimum satu kapsul teofilin tanpa dosis muatan, yaitu delapan ratus lima puluh milligram $(850,0063 \mathrm{mg})$ dengan potensi; $\mathrm{AX}_{1},=$ - 0,9076 dan $\mathrm{BX}_{2}=-1$ dengan teofilin $200 \mathrm{mg}$, maka berat maksimum kitosan dan metilselulosa masing-masing sebesar 609,2400 mg dan $20 \mathrm{mg}$.

\section{Formula Kitosan dan Metilselulosa Optimum}

Tabel 7 dan Gambar 2 menunjukkan hasil uji disolusi dan profil pelepasan teofilin dari sediaan formula dengan massa optimum satu kapsul 850 mg $\left(\mathrm{F}_{8}\right)$ yang mengandung massa kitosan dan metilseiulosa masing-masing sebesar 609,2400 $\mathrm{mg}$ dan $20 \mathrm{mg}$ dalam medium berbeda. Pelarutan teofilin dalam medium $\mathrm{I}(\mathrm{pH}=1,2)$ lebih lambat jika dibandingkan dalam medium II $(\mathrm{pH}=6,8)$. Hal ini karena teofilin bersifat asam lemah dengan harga $\mathrm{pKa}=8,6$ sehingga lebih mudah larut dalam medium yang bersifat basa dan mungkin pengaruh permeabilitas kitosan maupun metilselulosa terhadap medium II $(\mathrm{pH}=6,8)$ lebih besar daripada medium $\mathrm{I}(\mathrm{pH}=1,2)$. 
Tabel 7. Data Disolusi Granul Formula $F_{8}$ dalam Medium Berbeda

\begin{tabular}{|c|c|c|c|}
\hline \multirow{2}{*}{ No } & \multirow{2}{*}{$\begin{array}{c}\text { Waktu } \\
\text { (menit) }\end{array}$} & \multicolumn{2}{|c|}{ Persen Kumulatif Teofilin Terlarut } \\
\cline { 2 - 4 } & 30 & $8,3453 \pm 0,2479^{*}$ & $\mathrm{pH}=6,8$ \\
\hline 1 & 60 & $12,8644 \pm 0,4955$ & $22,4050 \pm 0,4179^{*}$ \\
\hline 2 & 90 & $15,8807 \pm 0,4647$ & $41,7365 \pm 1,1224$ \\
\hline 3 & 120 & $19,9823 \pm 0,4642$ & $51,9546 \pm 1,2665$ \\
\hline 4 & 150 & $25,7194 \pm 0,5357$ & $68,4271 \pm 0,9667$ \\
\hline 5 & 180 & $32,1670 \pm 0,6608$ & $76,6114 \pm 0,8198$ \\
\hline 6 & 210 & $35,4589 \pm 1,2082$ & $87,8080 \pm 1,1951$ \\
\hline 7 & 240 & $44,4921 \pm 0,4849$ & $92,1606 \pm 1,2010$ \\
\hline 8 & 270 & $51,3658 \pm 0,8052$ & $96,8700 \pm 1,0067$ \\
\hline 9 & & & $97,9637 \pm 1,0551$ \\
\hline
\end{tabular}

Keterangan : * Standar deviasi $(\mathrm{n}=6)$

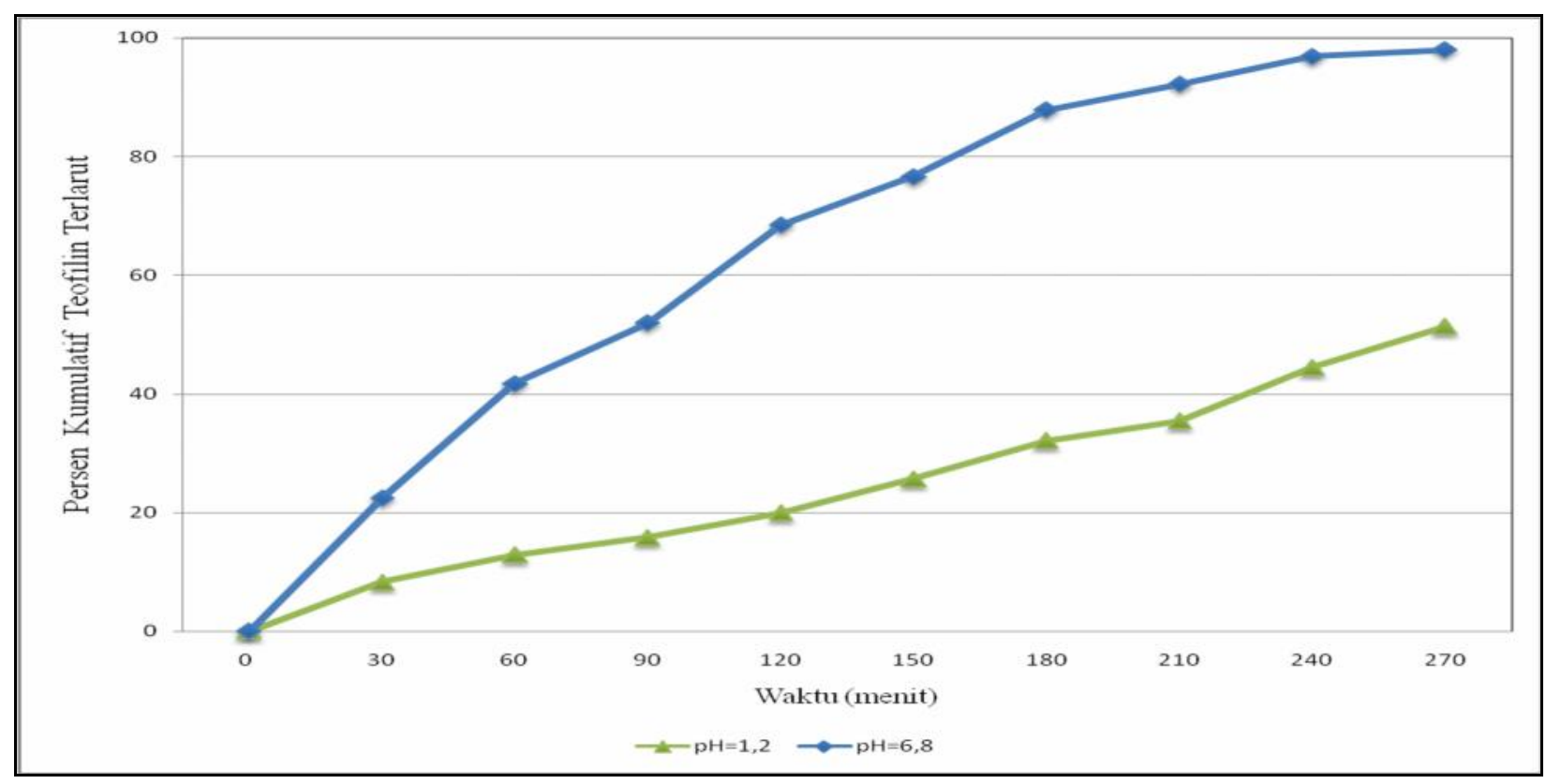

Gambar 2. Profil Pelepasan Teofilin Formula Optimum dalam Medium Berbeda

Koefisien determinasi terbesar pada medium I ( $\mathrm{pH}=1,2)$ dan medium II $(\mathrm{pH}=6,8)$ masingmasing sebesar 0,9744 dan 0,9631 (Tabel 8) menerangkan bahwa pelepasan obat dari formula $\mathrm{F}_{8}$ mengikuti orde no1 pada medium I dan Higuchi pada medium II. Hal ini terjadi karena teofilin bersifat asam lemah dengan harga $\mathrm{pKa}=$ 8,6 sehingga lebih mudah larut dalam medium yang bersifat basa dan mungkin pengaruh permeabilitas kitosan maupun metilselulosa terhadap medium II $(\mathrm{pH}=6,8)$ lebih besar daripada medium I $(\mathrm{pH}=1,2)$.

Tabel 8. Hasil Analisis Kinetika Pelepasan Teofilin dari Matriks Formula Optimum

\begin{tabular}{|c|c|c|c|c|}
\hline \multirow{2}{*}{ No } & \multirow{2}{*}{ Medium } & \multicolumn{3}{|c|}{ Nilai Koefisien Determinasi } \\
\cline { 2 - 5 } & & Orde Nol & Orde Satu & Orde Higuchi \\
\hline 1 & I & $\mathbf{0 , 9 7 4 4}$ & 0,9241 & 0,8000 \\
\hline 2 & II & 0,8616 & 0,9113 & $\mathbf{0 , 9 6 3 1}$ \\
\hline
\end{tabular}




\section{SIMPULAN DAN SARAN}

\section{Simpulan.}

Pelepasan teofilin makin lambat dengan kenaikan konsentrasi kitosan. Dan penambahan metilselulosa mempercepat pelepasan teofilin dari sediaan granul (Uji t, $\mathrm{p} \leq 0,05$ ).

Massa optimum kitosan dan metilselulosa dalam satu kapsul teofilin, yaitu $850 \mathrm{mg}$ adalah $609,24 \mathrm{mg}$ dan 20,00 mg. Pelepasan teofilin dari formula yang menggunakan pengikat campuran maksimum kitosan dengan metilselulosa sekitar 4,5 jam dengan persen kumulatif teofilin terlarut $(97,9637 \pm 1,0551) \%$ pada medium $\mathrm{pH}=6,8 . \mathrm{Uji}$ $\mathrm{t}$ tehadap pelepasan teofilin saat $\mathrm{t}=180$ menit antara penelitian dengan yang diharapkan, hasil prediksi tidak menunjukkan perbedaan yang nyata untuk uji dua pihak dengan $\alpha=0,05 ; \mathrm{dk}=5$ (t tabel $= \pm 2,57$ dan $t_{\text {hitung }}=-0,30$ ).

Laju pelepasan obat mengikuti orde Higuchi pada medium II dan orde nol pada medium I serta jenis sediaan granul termasuk pada prolonged action.

\section{Saran.}

Perlu dilakukan penelitian lebih lanjut dengan menggunakan obat yang mempunyai dosis pemakaian lebih kecil dari teofilin agar dihasilkan formula yang mempunyai berat satu sediaan pemakaian lebih kecil dari penelitian ini. Disamping itu perlu dicari pengikat selain metilselulosa, mengingat profil pelepasan bahan obat dari sediaan yang mengandung pengikat kombinasi khitosan dengan metilselulosa tidak memberikan pelepasan orde nol atau pengikat yang tidak larut dalam air agar pelepasan bahan obat lebih lama.

\section{DAFTAR PUSTAKA}

1. Shaji J, Jain V, Lodha S. Chitosan: A Novel Pharmaceutical Excipient. International Journal of Pharmaceutical and Applied Sciences. 2010; 1(1): 1-28.

2. Allache JM. Farmasetika 2. Biofarmasi. Edisi Surabaya: Airlangga University Press; 1993. p 154-339.

3. Lordi NG. Bentuk Sediaan Pelepasan Berkesinambungan. Dalam: Teori dan Praktek Farmasi Industri. Edisi III. jilid 2, editor: Leon Lachman, H.A. Lieberman dan J.L. Kanig, Jakarta: UI-Pres; 1994. p. 893940.

4. Barnes PJ. Theophylline. Pharmaceuticals. 2010; 3: 725-747

5. Rani M, Agarwal A, Maharana T, Negi YS. A Comparative Study for Interpenetrating Polymeric Network (IPN) of Chitosan Amino Acid Beads for Controlled Drug Release. African Journal of Pharmacy and Pharmacology. 2010; 4(2): 35-54.

6. Miyazaki S, Yamaguchi H, Yokouchi C, Takada M, How WM. Sustained Release of Indomethacin from Chitosan Granules in Beagle Dogs. J. Pharm. Pharmacol. 1988; 40 : 642-643

7. Knorr D. Dye Binding Properties of Chitin and Chitosan. J.Pharm.Sci. 1983; 48:36-41.

8. Matthew HW, Salley SO, Peterson, WD, Klien MD. Complex Coacenvte Microcapsules for Mammalian Cell Culture and Artificial Organ Development. J. Biotechnol. Prog. 1993; 9(5): 510.

9. Zielinski BA, Aebischer P. Chitosan as a Matrix for Mammalian Cell Encapsulation. J. Biomaterials. 1994; I5(13): 1049.

10. Siswanto A. Optimasi Formula Sediaan Tablet Lepas Lambat Teofilin dengan Bahan Matriks NaCMC dan Xanthan Gum. Pharmacy. 2006; 3(2): 40-45

11. Clarke EGC. Isolation and Identification of Drug. London: The Pharmaceutical Press; 1969. p. 270-271

12. Vashi VI, Meyer MC. Effect pH on the in Vitro Dissolution and in Vivo Absoption of Controlled-Release Theophilline in Dogs. J. Pharm. Sci. 1988; 77(9): 760-764.

13. Bolton S. Pharmaceutical Statistict Practical and Clinical Application. In: Drug and The Parmaceutical Sciences. editor: James Swarbrick. New York: Marcel Dekker, Inc; 1984. p.125-435.

14. Sudjana. Metode Statistik. Edisi Kelima. Bandung: Tarsito; 1992. p. 227-372.

15. Murtaza G, Ahmad M, Khan SA, dan Hussain I. Evaluation of Cefixime Loaded Chitosan Microspheres: Analysis of Dissolution Data Using DD Solver. [internet]. 2012. [cited 2013 August 12]. Available from: http://www.dissolutiontech.com/DTresour/20 1205Articles/DT201205_A02.pdf 